\title{
Screening of cowpea accessions for cowpea aphid resistance ${ }^{1}$
}

\author{
Antonia Débora Camila de Lima Ferreira ${ }^{2}$, Daniel Rodrigues Nere ${ }^{3}$, \\ Leandro Carvalho da Silva ${ }^{4}$, Ervino Bleicher ${ }^{3}$, Cândida Hermínia Campos de Magalhães Bertini ${ }^{3}$
}

ABSTRACT

Cowpea (Vigna unguiculata) genotypes may preserve important characteristics of potential use for the genetic breeding of this species. This study aimed to characterize sources of genetic resistance to the cowpea aphid (Aphis craccivora), among accessions maintained at the cowpea germplasm bank of the Universidade Federal do Ceará (Brazil), in order to suggest crossing options for obtaining superior cultivars. Twenty-one local accessions were assessed together with two genotypes as resistant checks and two others as susceptible checks. A randomized complete block design, with four replications, was used. Counts of live adults and nymphs per plant were used to evaluate the genotypic resistance and, based on the ranking of these data, the effective resistance was estimated. The applied approach showed to be effective to discriminate the genetic variability for cowpea aphid resistance, identifying antibiosis as the probable resistance mechanism. Four genotypic groups were identified: resistant, intermediate, susceptible and highly susceptible. Thus, for a short-time cultivar release strategy, backcrosses are suggested between the BRS Guariba cultivar (recurrent parental, with good agronomic traits) and aphidresistant accessions, such as Enrica Pobre (CE-36), Das Almas (CE-07), CE-51 (selected within CE-13) and Ritinha (CE-08). However, for a long-term breeding strategy, crossings between the most dissimilar accessions are suggested, using resistant genitors (e.g. BRS Guariba, Enrica Pobre, Das Almas, CE-51 and Ritinha) and others with good commercial and agronomic attributes.

KEYWORDS: Aphis craccivora, Vigna unguiculata, plant resistance to insects, genetic variability.

\section{INTRODUCTION}

Cowpea [Vigna unguiculata (L.) Walp.] is an important food crop and a basic component in the diet of rural and urban populations, in a variety

\section{RESUMO}

Triagem de acessos de feijão-caupi quanto à resistência ao pulgão-preto

Genótipos de caupi (Vigna unguiculata) podem preservar importantes características de uso potencial para o melhoramento genético dessa espécie. Objetivou-se caracterizar fontes de resistência genética ao pulgão do caupi (Aphis craccivora), entre acessos mantidos no banco de germoplasma de caupi da Universidade Federal do Ceará, buscando sugerir opções de cruzamento para a obtenção de cultivares superiores. Foram avaliados 21 acessos locais, juntamente com dois genótipos como padrões de resistência e outros dois como padrões de suscetibilidade. Utilizou-se delineamento em blocos completos casualizados, com quatro repetições. Contagens de adultos e ninfas vivos por planta foram utilizadas para avaliar a resistência genotípica e, a partir do ordenamento desses dados, foi estimada a resistência efetiva. A abordagem usada mostrouse eficiente na discriminação da variabilidade genética quanto à resistência ao pulgão-preto, identificando a antibiose como o provável mecanismo de resistência. Quatro grupos genotípicos foram identificados: resistente, intermediário, suscetível e altamente suscetível. Assim, para uma estratégia de liberação de cultivares em curto prazo, sugerem-se retrocruzamentos entre a cultivar BRS Guariba (genitor recorrente, com boas características agronômicas) e acessos resistentes ao pulgão, como Enrica Pobre (CE-36), Das Almas (CE-07), CE-51 (seleção dentro da CE-13) e Ritinha (CE-08). Já para uma estratégia de melhoramento a longo prazo, sugerem-se cruzamentos entre os acessos mais dissimilares, com o emprego de genitores resistentes (p. ex. BRS Guariba, Enrica Pobre, Das Almas, CE-51 e Ritinha) e outros de bons atributos comerciais e agronômicos.

PALAVRAS-CHAVE: Aphis craccivora, Vigna unguiculata, resistência de plantas a insetos, variabilidade genética.

of countries where it is produced by both large and small farmers (FAO 2017). Most of its production and consumption are concentrated in the African continent, where Nigeria is the main producer, with 3.7 million hectares cultivated and an average

1. Received: Mar. 26, 2019. Accepted: Aug. 12, 2019. Published: Mar. 06, 2020. DOI: 10.1590/1983-40632020v5057878.

2. Universidade Federal da Paraíba, Areia, PB, Brasil. E-mail/ORCID: deboracamilla1@hotmail.com/0000-0003-0650-2637.

3. Universidade Federal do Ceará, Fortaleza, CE, Brasil. Email/ORCID: danielnere@gmail.com/0000-0003-2653-4142, ervinob@gmail.com/0000-0003-3820-7114, cândida_bertini@yahoo.com.br/0000-0003-2949-5660.

4. Universidade Federal Rural da Amazônia, Belém, PA, Brasil. Email/ORCID: 1.carvalho.agro@gmail.com/ 
yield of $578 \mathrm{~kg} \mathrm{ha}^{-1}$ (FAO 2017). These numbers are considered lower than the actual potential of this crop, since, in other countries with a more technologically intensive agriculture, like the United States, yields exceed 1,500 kg ha-1 (FAO 2017). In Brazil, a similar pattern emerges, when comparing yields from different regions; for example, between the northeast $\left(414 \mathrm{~kg} \mathrm{ha}^{-1}\right)$ and midwest $\left(1,152 \mathrm{~kg} \mathrm{ha}^{-1}\right)$ of the country (Conab 2018).

The adaptability of this crop to different production systems is partly due to its genetic variability, which may be present in wild materials or preserved in active germplasm banks (Tsutsumi et al. 2015).

In order to preserve local cowpea accessions, the Universidade Federal do Ceará - UFC (Fortaleza, Ceará state, Brazil) created a germplasm bank in 1963, which now represents an important genetic heritage for the society (Paiva et al. 2014). The first entries in this collection consisted of three accessions (Bengala, Pitiúba and Seridó) from the Curu Valley (Pentecoste, Ceará state, Brazil), which were mainly studied for grain yield-related characteristics, but poorly evaluated for other agronomic traits, such as insect resistance (Paiva et al. 2014). For example, cowpea genotypes can host differently a variety of insect-pest species with great economic importance. Among these, cowpea aphid [Aphis craccivora Koch (Hemiptera: Aphididae)] is one of the most important cowpea pests in tropical regions of the world (Tanzubil et al. 2008), because it causes damages both directly (via suction of the plant sap) and indirectly (as an efficient virus vector).

Among the available methods for pest-insects control, the use of resistant plants is notable for its efficiency. The first research to identify resistant cowpea aphids on cowpea genotypes was carried out by Singh (1977), in Nigeria. In Brazil, such studies are more recent (Moraes \& Bleicher 2007, Silva \& Bleicher 2010, Silva et al. 2012, Valente et al. 2014, Bandeira et al. 2015), and there are still many accessions to be tested for this resistance. However, it is necessary to classify such materials not only in relation to resistance-related traits, but also for other agronomic capacities that they may have.

Accordingly, this study aimed to characterize sources of genetic resistance to $A$. craccivora in local accessions of $V$. unguiculata maintained at the UFC cowpea germplasm bank, in order to suggest potential crossings for the development of superior cultivars.

\section{MATERIAL AND METHODS}

The research was carried out at the Universidade Federal do Ceará, in Fortaleza, Ceará state, Brazil (03'40'24'S, 38 34'32'W and $12 \mathrm{~m}$ a.s.l.), in the second semester of 2015 , in an area covered with a 200-micron clear plastic roof and laterally protected by anti-aphid screens.

A total of twenty-one local accessions from the cowpea collection maintained at the UFC active germplasm bank were assessed. They were collected between 1963 and 1968, in the region of the Curu Valley. For comparison purposes, the TVu $408 \mathrm{P}_{2}$ and BRS Guariba cultivars were used as resistant checks, and VITA 7 and BR 17 Gurgueia as susceptible checks (Singh 1977, Moraes \& Bleicher 2007, Silva \& Bleicher 2010). The TVu $408 \mathrm{P}_{2}$ and VITA 7 cultivars were introduced from the International Institute of Tropical Agriculture (IITA), in Nigeria; while the BRS Guariba and BR 17 Gurgueia cultivars were developed by the Embrapa, in partnership with other Brazilian agricultural research institutions.

Unlike previous researches on this subject (Moraes \& Bleicher 2007, Silva \& Bleicher 2010, Silva et al. 2012) to reduce the experimental variation, a new cowpea aphid colony was created from an existing one, to achieve an age standardization of the insects to be used in the infestation. Between eight and ten seeds of the VITA 7 cultivar were sown in $2.8 \mathrm{~L}$ pots with a substrate of sieved sand, worm humus and vermiculite, in a respective 6:3:1 ratio, for a total of six pots. At 14 days after sowing, the resulting plants were infested with five wingless, rounded, adult female aphids with bright black color. At 24 hours after the infestation, the adult insects were eliminated, leaving only freshly-deposited nymphs, and, at six days after the initial infestation, adult insects with the same age were used for the experimentation.

Each one of the 25 genotypes (treatments) was sown in labeled $300 \mathrm{~mL}$ polyethylene pots containing the same substrate previously described. Two seeds were planted per pot and, after five days, thinned, leaving one plant. Each plant of a given genotype was considered a plot, and the plots were arranged in a randomized complete block design, with four replications. The blocks were arranged in lined cages with anti-aphid mesh $(1.0 \mathrm{~m} \times 1.0 \mathrm{~m} \times 0.50 \mathrm{~m})$ to prevent aphids and their natural enemies, as well as any other insect, from entering. 
At ten days after sowing, the treatments were infested with five six-day-old adult insects per plant. After 48 hours of infestation, all living adults were counted and removed, with the number of live nymphs counted after 96 hours. To evaluate the genotype resistance, the number of live adults and live nymphs were used. The obtained data were transformed by the expression $(\mathrm{X}+0.5)^{0.5}$, and univariate variance analyses were performed with the treatment means, separated by a Scott-Knott test at $5 \%$ of probability.

With the average values for number of adults and nymphs on each plant genotype, the resistance measures could be ranked using the Mulamba \& Mock (1978) method. Here, the lower the ranking score for the average number of insects, the greater is the aphid resistance of the genotype (i.e., it hosted fewer adult insects and nymphs). The sum of the ranks for the number of live adults and nymphs also allowed to estimate the effective resistance. This is a concept related to the joint action of plant components on the survival of adult insects and nymphs. It is assumed that an effective resistance provides an approximate model to the reaction of the plant to the insects under field conditions, and, therefore, this variable was also ranked.

A new analysis of variance was performed based on the rankings for the number of adults and nymphs, as well as the effective resistance. This provided the mean rank variable (Xr), whose value represents the resistance potential of the genotype against the cowpea aphid attack. The means were separated by the Scott-Knott method at $5 \%$ of probability.

A cluster analysis was performed taking into account the number of live adults and live nymphs, based on the generalized Mahalanobis distances and unweighted mean pairing grouping method (UPGMA), in order to identify accessions groups with similarity for aphid resistance. For this analysis, including the respective dendrogram, the Genes software (Cruz 2006) was used.

\section{RESULTS AND DISCUSSION}

The univariate statistical analysis for number of adult aphids separated the genotypic means into two groups, here called "resistant" and "susceptible" (Table 1). The cowpea accessions Enrica Pobre (CE-36), Das Almas (CE-07), CE-51 and Ritinha
(CE-08) were statistically similar $(p>0.05)$ to the resistant genotypes used as check (BRS Guariba and $\mathrm{TVu} 408 \mathrm{P}_{2}$ ), with the lowest numbers of adult insects. However, the Bengala accession had more adult insects than initially infested, differing from the resistant checks, but with a similar mean to those genotypes used as susceptibility patterns.

For the adult insects, in the case of a choice trial, one or more of the following events may occur: antibiosis, due to insect mortality caused by some substance (Obopile \& Ositile 2010); antixenosis, due to escape caused by some repellent substance (Annan et al. 1997); or temporary attractiveness favored by the presence of a group of up to ten individuals (Pettersson et al. 1998). The latter was observed in the Bengala (CE-02) accession, with an average of 5.5 for live adults, indicating that this form attracts aphids due to characteristics of the plant and/or insects. Moraes \& Bleicher (2007) reported a similar situation with the Pitiúba cowpea cultivar against cowpea aphid, which had, on average, more aphids (5.17) than initially experimentally placed on the material (five aphids).

The number of produced nymphs can also be used to assess antibiosis-based resistance (Ahman 2009). For this variable, the cowpea accessions were separated into two groups of means (Table 1), using the same methods as for the number of adults. The results resembled those obtained for adults, with the accessions Enrica Pobre (CE-36), Das Almas (CE-07), CE-51 and Ritinha (CE-08) having the smallest number of nymphs. Antibiosis indicates the existence of antagonistic substances in plants, such as flavonoids and tannins (Taiz et al. 2017), and the mortality of aphids may be related to the concentration of these substances and the age of the insects, when subjected to such a toxin (Panizzi \& Parra 2009).

Aphids present a viviparous parthenogenesis, so that an adult female already has daughters and granddaughters forming inside (Ogawa \& Miura 2014). Thus, it is likely that small amounts of antibiotics substances may kill such nascent individuals, even while they are still inside the adult insect. Overall, this results in fewer offsprings, even if the parent female is not directly affected. Under such circumstances, even moderate plant resistance becomes useful to the farmer, as the effect tends to be cumulative.

The average rank (Xr), based on mean rankings of primary (number of live adults and nymphs) and 
Table 1. Means ${ }^{1}$ of cowpea accessions (Vigna unguiculata) for number of live adults (NA) and live nymphs (NN) of cowpea aphid (Aphis craccivora) on individual plants, after artificial infestation, and indexes for effective resistance (ER) and resistance ranking $(\mathrm{Xr})$ estimated from trial to assess the cowpea resistance to this insect.

\begin{tabular}{|c|c|c|c|c|c|c|c|c|}
\hline Genotype & $\mathrm{Code}^{2}$ & $\mathrm{~N}$ & $\bar{z}$ & $-\mathrm{N}$ & 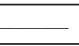 & 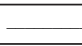 & & $\mathrm{Xr}^{5}$ \\
\hline BRS Guariba & - & $0.00 \mathrm{~b}$ & (1) & $7.75 \mathrm{~b}$ & (1) & 2 & (1) & $1.00 \mathrm{~d}$ \\
\hline Enrica Pobre & CE-36 & $0.25 \mathrm{~b}$ & (2) & $9.25 \mathrm{~b}$ & (2) & 4 & (2) & $2.00 \mathrm{~d}$ \\
\hline Das Almas & CE-07 & $0.25 \mathrm{~b}$ & (2) & $10.5 \mathrm{~b}$ & (3) & 5 & (3) & $2.67 \mathrm{~d}$ \\
\hline Selected within CE-13 & CE-51 & $0.50 \mathrm{~b}$ & (3) & $11.0 \mathrm{~b}$ & (4) & 7 & (4) & $3.67 \mathrm{~d}$ \\
\hline $\mathrm{TVu} 408 \mathrm{P}_{2}$ & - & $1.50 \mathrm{~b}$ & (5) & $15.25 \mathrm{~b}$ & (5) & 10 & (5) & $5.00 \mathrm{~d}$ \\
\hline Ritinha & CE-08 & $1.25 \mathrm{~b}$ & (4) & $30.00 \mathrm{~b}$ & (6) & 10 & (5) & $5.00 \mathrm{~d}$ \\
\hline CE-55 & CE-55 & $2.75 \mathrm{a}$ & (6) & $45.75 \mathrm{a}$ & (7) & 13 & (6) & $6.33 \mathrm{c}$ \\
\hline Praiano & CE-74 & $3.25 \mathrm{a}$ & (7) & $59.25 \mathrm{a}$ & (9) & 16 & (7) & $7.67 \mathrm{c}$ \\
\hline Quarenta dias-1 & CE-70 & $3.75 \mathrm{a}$ & (9) & $54.50 \mathrm{a}$ & (8) & 17 & (8) & $8.33 \mathrm{c}$ \\
\hline Africano-1 & CE-19 & $3.75 \mathrm{a}$ & (9) & $62.75 \mathrm{a}$ & (10) & 19 & (9) & $9.33 \mathrm{c}$ \\
\hline Seridó & CE-01 & $3.25 \mathrm{a}$ & (7) & $71.75 \mathrm{a}$ & (12) & 19 & (9) & $9.33 \mathrm{c}$ \\
\hline Sete semanas & CE-72 & $3.50 \mathrm{a}$ & (8) & $76.50 \mathrm{a}$ & (13) & 21 & (10) & $10.3 \mathrm{~b}$ \\
\hline Seleção CE-42 & CE-47 & $4.25 \mathrm{a}$ & (11) & $67.25 \mathrm{a}$ & (11) & 22 & (11) & $11.0 \mathrm{~b}$ \\
\hline Vinagre-1 & CE-03 & $4.00 \mathrm{a}$ & (10) & $78.50 \mathrm{a}$ & $(15)$ & 25 & (12) & $12.3 \mathrm{~b}$ \\
\hline Rabo-de-calango & CE-67 & $4.25 \mathrm{a}$ & (11) & $78.00 \mathrm{a}$ & (14) & 25 & (12) & $12.3 \mathrm{~b}$ \\
\hline Pitiúba & CE-31 & $4.25 \mathrm{a}$ & (11) & $79.25 \mathrm{a}$ & (16) & 27 & (13) & $13.3 \mathrm{~b}$ \\
\hline Fígado-de-galinha & CE-64 & $4.00 \mathrm{a}$ & (10) & $80.00 \mathrm{a}$ & (17) & 27 & (13) & $13.3 \mathrm{~b}$ \\
\hline BR 17 Gurgueia & - & $4.00 \mathrm{a}$ & (10) & $80.50 \mathrm{a}$ & (18) & 28 & (14) & $14.0 \mathrm{~b}$ \\
\hline Roxão-1 & CE-13 & $4.00 \mathrm{a}$ & (10) & $89.75 \mathrm{a}$ & (20) & 30 & (15) & $15.0 \mathrm{a}$ \\
\hline Cabecinha & CE-04 & $4.75 \mathrm{a}$ & (13) & $88.25 \mathrm{a}$ & (19) & 32 & (16) & $16.0 \mathrm{a}$ \\
\hline Isabel-1 & CE-10 & $4.50 \mathrm{a}$ & (12) & $90.00 \mathrm{a}$ & (21) & 33 & (17) & $16.7 \mathrm{a}$ \\
\hline VITA-7 & - & $4.25 \mathrm{a}$ & (11) & $90.50 \mathrm{a}$ & (22) & 33 & (17) & $16.7 \mathrm{a}$ \\
\hline Rita Joana & CE-12 & $4.25 \mathrm{a}$ & (11) & $94.00 \mathrm{a}$ & (23) & 34 & (18) & $17.3 \mathrm{a}$ \\
\hline Milagroso & CE-46 & $4.75 \mathrm{a}$ & (13) & $95.75 \mathrm{a}$ & (24) & 37 & (19) & $18.7 \mathrm{a}$ \\
\hline Bengala & CE-02 & $5.50 \mathrm{a}$ & (14) & $109.50 \mathrm{a}$ & (25) & 39 & (20) & $19.7 \mathrm{a}$ \\
\hline
\end{tabular}

Means followed by the same letter in the column are not statistically different, according to the Scott-Knott method at $5 \%$ of probability. ${ }^{2}$ Accession code of genotypes in the active germplasm bank of the Universidade Federal do Ceará. ${ }^{3}$ The original data (for NA and NN) were transformed as $(\mathrm{X}+0.5)^{0.5} .{ }^{4} \mathrm{Values}$ within parentheses are the respective mean ranks in each column. ${ }^{5}$ Mean rank according to the Mulamba \& Mock (1978) method.

secondary (effective resistance) variables, provides an indication of the resistance of each accession to the cowpea aphid attack. Accordingly, the Xr means were separated into four statistical groups (Table 1): i) resistant accessions - Enrica Pobre, Das Almas, selection within CE-13 (CE-51) and Ritinha, as well as the resistant checks BRS Guariba and TVu $408 \mathrm{P}_{2}$; ii) accessions with intermediate resistance (patterns that differed from both the resistant and susceptible forms) - CE-55, Praiano (CE-74), Quarenta dias-1 (CE-70), Africano-1 (CE-19) and Seridó (EC-01); iii) susceptible accessions - Sete semanas (CE-72), CE-47 (a selection in CE-42), Vinagre-1 (CE-03), Rabo-de-calango (CE-67), Pitiúba (CE-31), Fígado-degalinha (CE-64) and BR 17 Gurgueia; iv) highly aphidsusceptible accessions - Roxão-1 (CE-13), Cabecinha (CE-04), Isabel-1 (CE-10), VITA 7, Rita Joana (CE-12), Milagroso (CE-46) and Bengala (CE-02).

Among the evaluated accessions, Pitiúba and Sete semanas were classified as susceptible, and Milagroso as highly susceptible. All of them were also classified as susceptible to cowpea aphid by Silva et al. (2012), corroborating the results of the present study. However, the Seridó accession, classified as intermediate, was considered susceptible by Silva \& Bleicher (2010). This difference may be due to methodological variation, since, unlike in that study, in the current research, an age-standardized colony was used to ensure that all individuals in the trial were in the same developmental phase.

The Roxão-1 (CE-13) accession was highly susceptible to aphids. There is no reference in the available literature regarding some deliberate or targeted selection on cowpea aphid resistance on the germplasm bank here studied. However, it is known that the accessions of this collection are multiplied, on average, every five years (Barreto 1999), to maintain the physiological characteristics of the seeds, and other studies are performed, including selections at the bank curator discretion. Probably, the plant that 
gave rise to the CE-51 access from selection within the susceptible access CE-13 must have caught the curator attention for its superior performance, and now is identified as resistant. This fact may be related to segregation in the original access.

The nomenclature for local accessions is often strongly influenced by their agronomic characteristics. Producers from the Curu Valley describe the Enrica Pobre accession as "high yielding, resistant and long-lasting" (Araújo et al. 2006). Given the history of aphids in cultivated areas of this region, the success of this variety may be related to its high resistance to cowpea aphids under cultivation conditions, thus contributing even to its commercial name, which means "enriches the poor man".

Taking into account the narrow genetic base of Brazilian cowpea cultivars (Montalván et al. 2006) and the biological characteristics of aphids, the genetic variability for cowpea aphid resistance of the accessions reported here provides an important resource to be explored by breeding programs.

After the multivariate analysis, the adoption of an arbitrarily cut-off point of $50 \%$ in the dendrogram shown in Figure 1 gave rise to two distinct groups (A and B). The first (A) contains the accessions Ritinha, Enrica Pobre, CE-51 and Das Almas, as well as the resistant checks TVu $408 \mathrm{P}_{2}$ and BRS Guariba; and the latter a cultivar in wide commercial use. The other group (B) jointed all the other accessions and the susceptible checks VITA 7 and BR 17 Gurgueia.

A second cut-off distance of $5 \%$ was used to obtain subgroups from the first clustering (Figure 1), what allowed to choose better genotypes to be used as parentals for future crossings in a breeding program. In the group $\mathrm{A}$, this gave rise to three subgroups: A1 - with only the TVu $408 \mathrm{P}_{2}$ introduction; A2 - with only the Ritinha (CE-08) accession; and A3 - with CE-51, BRS Guariba, Enrica Pobre (CE-36) and Das Almas (CE-07). In the group $\mathrm{B}$, three subgroups were identified: B1 - Praiano (CE-74), CE-55 (CE-55), Quarenta dias-1 (CE-70), a selection in CE-42 (CE-47) and Africano-1 (CE-19); B2 - with only the Bengala accession (CE-02); and B3 - with the two susceptible checks (VITA 7 and BR 17 Gurgueia) and the remaining accessions: Sete semanas (CE-72), Seridó (CE-01), Milagroso (CE-46), Isabel-1 (CE-10), Roxão-1 (CE-13), Rita Joana (CE-12), Fígado-de-galinha (CE-64),

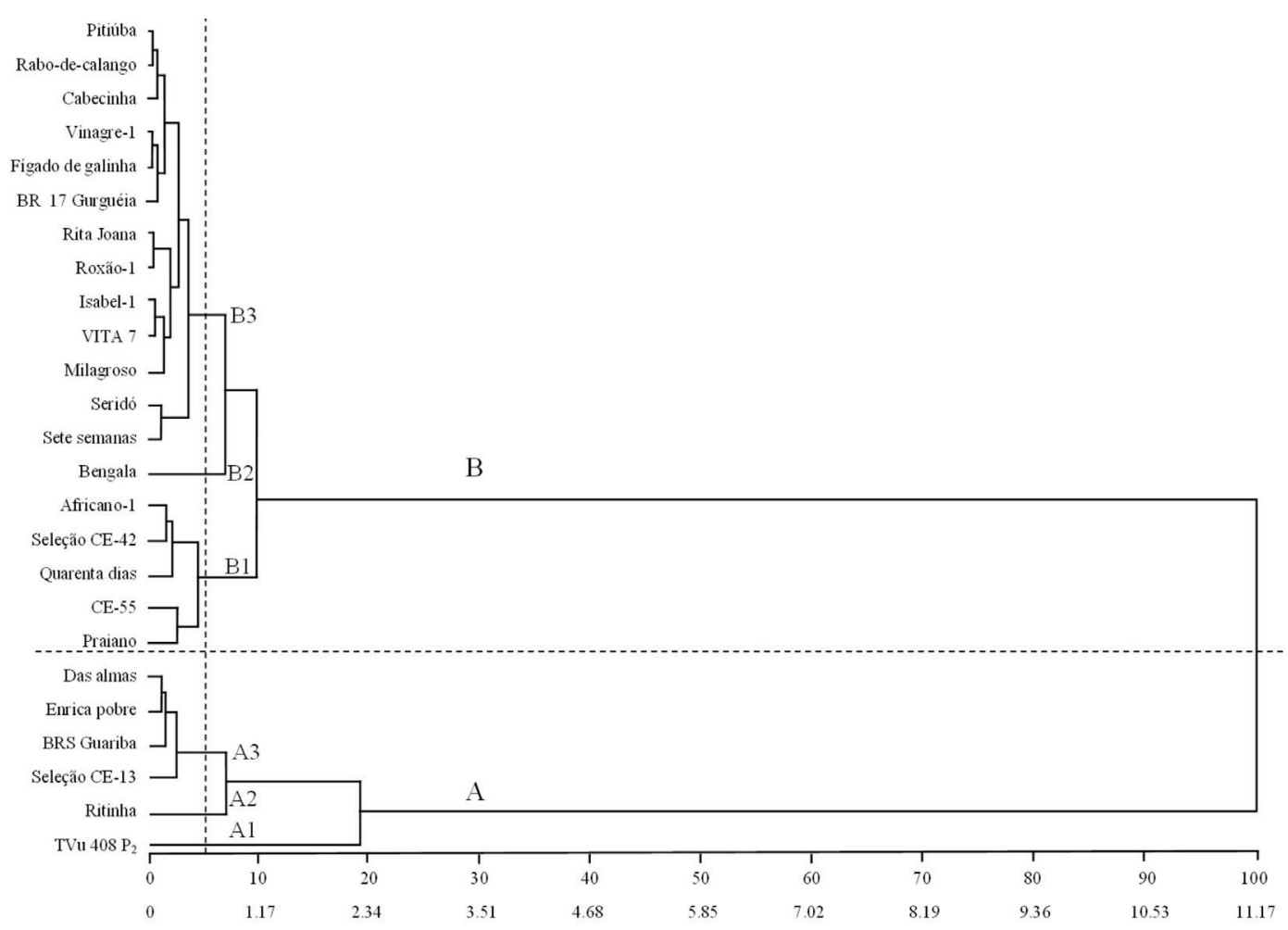

Figure 1. Dendrogram resulting from a cluster analysis, using generalized Mahalanobis distances on the variables number of live cowpea aphid adults and nymphs, for cowpea accessions from an active germplasm bank, with indication of two cut-off points $(5 \%$ and $50 \%)$ for genotypic grouping (cophenetic correlation $=0.93 ; \mathrm{p}<0.01)$. 
Vinagre-1 (CE-04), Cabecinha (CE-04), Rabo-decalango (CE-67) and Pitiúba (CE-31).

Based on the results from genetic divergence, plans for crossings can be defined to obtain new cowpea aphid-resistant cultivars. To achieve a cultivar that can be released in the short term, backcrosses between the widely marketed BRS Guariba cultivar and one of the resistance source genotypes (Enrica Pobre, Das Almas, CE-51 and Ritinha) are suggested.

On the other hand, for a long-term breeding program, crossings between the most dissimilar genotypes are suggested. These hybrid combinations may lead to greater heterotic effects and genetic gain, with formation of superior hybrid genotypes. Under such circumstances, crossings could involve resistant genotypes (BRS Guariba, Enrica Pobre, Das Almas, CE-51 and Ritinha) and accessions that were most dissimilar and had the greatest commercial potential (agronomic, culinary and cultural attributes), such as Pitiúba, Rabo-de-calango, Cabecinha, Vinagre-1, Fígado-de-galinha, Rita Joana, Roxão-1, Isabel-1, Milagroso, Seridó, Sete semanas and Bengala (Paiva et al. 2014).

In general, all crossings should be restricted to combinations of the best genotypes, from an agronomic point of view, including, according to the proposal of this study, the genetic resistance to A. craccivora as the main characteristic to be transferred. The genotypes initially collected to establish the active germplasm bank here studied, according to Paiva et al. (2014), are Seridó (CE-01), Bengala (CE-02) and Pitiúba (CE-31), which were used as parentals in the initial crossings made at the Universidade Federal do Ceará. On the other hand, the accessions Das Almas (CE-07), Ritinha (CE-08), Enrica Pobre (CE-36) and CE-51 (selection within Roxão-1, coded as CE-13), which, in this study, showed resistance to A. craccivora, were not used as parental genotypes in these initial crossings. As a result, the current study underscores the importance of this germplasm bank for the genetic resources conservation, revealing the potential of the accessions in the collection to be used in future crossings, aiming, for example, to incorporate resistance to cowpea aphid.

\section{CONCLUSIONS}

1. The analytical approach here employed showed to be effective for the screening of genetic variability among cowpea accessions for Aphis craccivora resistance. Four genotypic groups (resistant, intermediate, susceptible and highly susceptible) characterize the studied germplasm collection, in which antibiosis is the probable resistance mechanism;

2. Backcrosses between the BRS Guariba cultivar (recurrent parent, with good agronomic characteristics) and aphid-resistant genotypes such as Enrica Pobre, Das Almas, CE-51 or Ritinha are suggested for a short-time cultivar release goal. As a long-term goal, crossings between one of these resistant genotypes and the other most dissimilar accessions that have good agronomic attributes are suggested.

\section{REFERENCES}

AHMAN, I. Breeding for inducible resistance against insects: applied plant breeding aspects. IOBC-WPRS Bulletin, v. 44, n. 1, p. 121-130, 2009.

ANNAN, I. B.; SCHAEFERS, G. A.: TINGEY, W. M.; TJALLINGII, W. F. Stylet activity of cowpea aphid (Homoptera: Aphididae) on leaf extracts of resistant and susceptible cowpea cultivars. Journal of Insect Behavior, v. 10, n. 5, p. 603-618, 1997.

ARAÚJO, M. R. A.; VASCONCELOS, H. E. M.; SOUSA, F. B. Resgatando e preservando a base genética da bacia do Rio Curu, Ceará: alguns resultados e considerações preliminares. In: CONGRESSO DA SOCIEDADE BRASILEIRA DE ECONOMIA E SOCIOLOGIA RURAL, 2006, Fortaleza. Anais... Fortaleza: Embrapa Agroindústria Tropical, 2006. p. 1-10.

BANDEIRA, H. F. S.; LIMA, A. C. S.; STRUCKER, A. C. S. L.; TRASSATO, L. B.; DIONÍSIO, L. F. S. Preferência do pulgão-preto e da cigarrinha-verde em diferentes genótipos de feijão-caupi em Roraima.Agro@mbiente On-line, v. 9, n. 1, p. 79-85, 2015.

BARRETO, P. D. Recursos genéticos e programa de melhoramento de feijão-de-corda no Ceará: avanços e perspectivas. In: QUEIRÓZ, M. A.; GOEDERT, C. O.; RAMOS, S. R. R. (ed.). Recursos genéticos e melhoramento de plantas para o nordeste brasileiro. Petrolina: Embrapa Semiárido, 1999. Disponível em: http://www.cpatsa.embrapa.br. Acesso em: 06 mar. 2020.

COMPANHIA NACIONAL DE ABASTECIMENTO (Conab). Acompanhamento da safra brasileira de grãos: sétimo levantamento: safra 2018/19. 2018. Disponível em: http://www.conab.gov.br. Acesso em: 13 ago. 2019.

CRUZ, C. D. Programa Genes: estatística experimental e matrizes. Viçosa: Ed. UFV, 2006. 
FOOD AND AGRICULTURE ORGANIZATION OF THE UNITED NATIONS (FAO). Faostat. 2017. Disponível em: http://faostat.fao.org/site/567/DesktopDefault. aspx?PageID=567\#ancor. Acesso em: 14 ago. 2019.

MONTALVÁN, R.; MAIA, J. P.; MACIEL, S. V. P. A.; RAMOS, S. R. R.; FREIRE FILHO, F. R. Base genética das cultivares brasileiras de feijão-caupi. In: CONGRESSO NACIONALDE FEIJÃO-CAUPI; REUNIÃONACIONAL DE FEIJÃO-CAUPI, 2006, Teresina. Anais... Teresina: Embrapa Meio Norte, 2006. p. 1-5.

MORAES, J. G. L.; BLEICHER, E. Preferência do pulgãopreto, Aphis craccivora Koch, a diferentes genótipos de feijão-de-corda, Vigna unguiculata (L.) Walp. Ciência Rural, v. 37, n. 6, p. 1554-1557, 2007.

MULAMBA, N. N.; MOCK, J. J. Improvement of yield potential of the Eto Blanco maize (Zea mays L.) population by breeding for plant traits. Egyptian Journal of Genetics and Cytology, v. 7, n. 1, p. 40-51, 1978.

OBOPILE, M.; OSITILE, B. Life table and population parameters of cowpea aphid, Aphis craccivora Koch (Homoptera: Aphididae) on five cowpea Vigna unguiculata (L. Walp.) varieties. Journal of Pest Science, v. 83, n. 1, p. 9-14, 2010.

OGAWA, K.; MIURA, T. Aphid polyphenisms: transgenerational development regulation through viviparity. Frontiers in Physiology, v. 5, n. 1, p. 1-11, 2014.

PAIVA, J. B.; FREIRE FILHO, F. R.; TEÓFILO, E. M.; RIBEIRO, V. Q. Feijão-caupi: melhoramento genético no Centro de Ciências Agrárias. Fortaleza: Ed. UFC, 2014.

PANIZZI, A. R.; PARRA, J. R. P. Bioecologia e nutrição de insetos: base para o manejo integrado de pragas. Brasília, DF: Embrapa, 2009.
PETTERSSON, J.; KARUNARATNE, S.; AHMED, E.; KUMAR, V. The cowpea aphid, Aphis craccivora, host plant odors and pheromones. Entomologia Experimentalis et Aplicata, v. 88, n. 2, p. 177-184, 1998.

SILVA, J. F.; BERTINI, C. H. C.; BLEICHER, E.; MORAES, J. G. L. Divergência genética de genótipos de feijão-de-corda quanto à resistência ao pulgão-preto. Pesquisa Agropecuária Brasileira, v. 47, n. 7, p. 948-954, 2012.

SILVA, J. F.; BLEICHER, E. Resistência de genótipos de feijão-de-corda ao pulgão-preto. Pesquisa Agropecuária Brasileira, v. 45, n. 10, p. 1089-1094, 2010.

SINGH, S. R. Cowpea cultivars resistant to insect pests in world germplasm collection. Tropical Grain Legume Bulletin, v. 9, n. 1, p. 3-7, 1977.

TAIZ, L.; ZEIGER, E.; MOLLER, I.; MURPHY, A. Fisiologia e desenvolvimento vegetal. 6. ed. Porto Alegre: Artmed, 2017.

TANZUBIL, P. B.; ZAKARIAH, M.; ALEM, A. Integrating host plant resistance and chemical control in the management of cowpea pests. Australian Journal of Crop Science, v. 2, n. 3, p. 115-120, 2008.

TSUTSUMI, C. Y.; BULEGON, L. G.; PIANO, J. T. Melhoramento genético do feijoeiro: avanços, perspectivas e novos estudos, no âmbito nacional. Revista Nativa, v. 3, n. 3, p. 217-223, 2015.

VALENTE, E. C. N.; TRINDADE, R. C. P.; BROGLIO, S. M. F.; DUARTE, A. G.; RODRIGUES, V. M.; LIMA, H. M. A.; BATISTA, N. S.; SANTOS, J. R. Aspectos biológicos de Aphis craccivora Koch (Hemiptera: Aphididae) em cultivares de feijão-caupi Vigna unguiculata (L.) Walp. Ciência Agrícola, v. 12, n. 1, p. 17-20, 2014. 